\title{
The origins of oncomice: a history of the first transgenic mice genetically engineered to develop cancer
}

\author{
Douglas Hanahan, ${ }^{1,4}$ Erwin F. Wagner, ${ }^{2}$ and Richard D. Palmiter ${ }^{3}$ \\ ${ }^{1}$ Department of Biochemistry and Biophysics, Diabetes Center, and Comprehensive Cancer Center, University of California \\ at San Francisco, San Francisco, California 94143, USA; ${ }^{2}$ Research Institute for Molecular Pathology (IMP), Vienna A-1030, \\ Austria; ${ }^{3}$ Department of Biochemistry, University of Washington, Seattle, Washington 98195, USA
}

This perspective describes the concurrent development in the 1980s of the first transgenic mice genetically engineered to express dominant oncogenes, involving independent researchers who were largely unaware of each other's strategies and progress. We relate the experimental designs, the pitfalls and challenges encountered, and the eventual success in developing distinctive mouse models of cancer, wherein tumors arose heritably in various organs. These early oncomice have produced a wealth of new knowledge, become topics of intellectual property, and spawned a vibrant field of cancer research that is revealing mechanisms of tumorigenesis and suggesting new therapeutic strategies for treating the human disease.

Supplemental material is available at http://www.genesdev.org.

In the early 1980s, a technology for generating lines of "transgenic mice" carrying cloned genes integrated into the mouse genome was demonstrated to be a tractable and reproducible method (Gordon et el. 1980; Brinster et al. 1981; Costantini and Lacy 1981; Wagner et al. 1981; for review, see Palmiter and Brinster 1986). Concurrently, there was considerable excitement in cancer research, with the continuing discoveries and molecular cloning of viral and then cellular oncogenes. These genes were causally implicated in particular natural cancers and demonstrably capable of inducing transformation of cultured cells that would form tumors when transplanted in appropriate host animals. The two areas of research came together when transgenic mice carrying cloned oncogenes were generated and found in some cases to have heritable predispositions to the development of cancer. The first reports appeared in 1984, with others following in 1985-1987, collectively substantiating the hypothesis that oncogene expression in normal

[Keywords: Transgenic mice; mouse models of human cancer; oncogenes; tumors; oncomouse patents]

${ }^{4}$ Corresponding author.

E-MAIL dh@biochem.ucsf.edu; FAX (415) 731-3612.

Article is online at http://www.genesdev.org/cgi/doi/10.1101/gad.1583307. cells within normal tissues of a mammalian organism could lead to tumor development. In 1992, gene knockout technology converged in a similar fashion with tumor suppressor genetics in the generation of mice that developed cancers by virtue of lacking tumor suppressor gene function (for review, see Jacks 1996).

The significance of these early technological innovations, which lead to genetically engineered mice endowed to heritably develop particular forms of cancer, can be appreciated by considering the scientific/technical landscape then, and now. Before these developments, cancer was largely modeled by tissue culture of cell lines established from human and animal tumors, and by the inoculation (transplantation) of such cell lines under the skin of immunodeficient mice, where lump-like solid tumors would form. While of clear utility in studying parameters of tumor growth, such models did not necessarily recapitulate the subtleties observed in human tumors arising in different organs, in terms of polymorphic genetic susceptibility, histological characteristics, and progression from benign premalignant lesions to tumors of increasing aggressiveness. Moreover, tumor transplant models, while frequently used as a benchmark to document activity of anti-cancer drugs in preclinical therapeutic trials, did not necessarily predict the limited benefits or failures seen when some such drugs were subsequently tested in clinical trials (Kerbel 2003; Sharpless and DePinho 2006). In an insightful alternative approach to tumor transplant models, Rudolf Jaenisch and Beatrice Mintz (Jaenisch and Mintz 1974) sought to introduce the genome of the SV40 DNA tumor virus into mice via viral infection of early embryos; although the resultant SV40-containing mice did not transmit the SV40 genome to progeny or evidence tumors, the approach reflects on the subsequent development of tumor-prone oncomice.

In the current era, in addition to such transplant tumor models, the biomedical research community has at its disposal an ever-expanding set of research tools, consisting of hundreds of mouse models of organ-specific cancer, wherein tumors arise out of normal cells resident in their natural tissue microenvironments in the context of 
intact immune systems and other tissue-intrinsic barriers to tumorigenesis. These models in some cases recapitulate the genetic mutations, the polymorphic genetic susceptibility and resistance, the histological subtleties, and/or the progressions that are characteristic of different types and subtypes of human cancer. These research tools provide new insights into the mechanisms of cancer development and progression, and present platforms for testing experimental therapeutics in conditions that may more accurately mimic different human cancers. Scientific conferences regularly focus on these engineered mouse models of cancer and draw thousands of scientists every year to exchange new results and ideas. The breadth of involvement by the cancer research community, the excitement of the new knowledge forthcoming, and the future promise of this burgeoning field are apparent, arguably unimaginable when these mouse models were first being developed. At the time it was not self-evident that such early models could be built or that they would be so extraordinarily useful, in and of themselves, as prototypes for a new field of cancer research.

In this historical reflection, we focus on the concurrent development of the first transgenic mice carrying dominant oncogenes, termed "oncomice," involving four independent research groups who were largely unaware of each other's strategies, efforts, and progress. We present a perspective on how experimental designs evolved in each of the groups, on the pitfalls and challenges they encountered, and on their eventual success in developing transgenic mouse models of cancer. This treatise does not seek to cover the equally important development of gene knockout technology or the sophisticated second- and third-generation models that have been engineered to further refine mouse models as reflective of human cancers to better enable investigation of mechanisms and testing of new therapies. Rather, our focus is on the early days of oncomice and on the lessons forthcoming from their engineering and initial analysis.

\section{Richard Palmiter and Ralph Brinster: transgenic mice developing brain and lymphoid tumors}

The collaboration between Richard Palmiter and Ralph Brinster began in the fall of 1980, initiated by a series of phone conversations. Their entrée into transgenic mice began with a hybrid gene that Allen Senear, a post-doctoral fellow in Palmiter's laboratory, had constructed. The recombinant gene, called $M K$, consisted of the mouse metallothionein-1 gene $(M t 1)$ promoter fused to transcribe the thymidine kinase $(T K)$ gene from herpes simplex virus (HSV). At that time, the $H S V$-TK gene was being used both as a selectable gene in TK-null cells and as a convenient reporter gene. Palmiter was interested in asking whether regulation of metallothionein promoter activity by metals or hormones could be conferred onto HSV-TK expression after DNA injection into mouse eggs. Brinster was excited by the prospect of transferring fertilized eggs microinjected with this reporter gene into pseudopregnant females. The idea was to see if the gene would be retained and, if so, if it would be functional in adult mice that developed from the injected eggs. This experiment led to their first transgenic mice (Brinster et al. 1981). They found that HSV-TK enzyme activity was induced in the liver of the transgenic mice by metals known to activate the endogenous $M t 1$ gene, and that the transgenes could be transmitted to progency and retain expression (Palmiter et al. 1982b).

Even before the report of their first transgenic mice was published, Palmiter and Brinster began talking about other genes they might express from the $M t 1$ gene promoter. Among the candidates were growth hormone and oncogenes. They first met in November 1981, when Richard Palmiter visited Ralph Brinster in Philadelphia (Fig. 1A). Their transcontinental collaboration was maintained by 2- to 3-h telephone calls every Saturday, a tradition that continued for 15 years.

Palmiter and Brinster's development of tumor-prone transgenic mice came from a convergence of sorts, involving both a deliberate aim (initially unsuccessful) to produce transgenic mice expressing cellular oncogenes and a serendipitous approach (unexpectedly successful) originally intended to amplify the levels of transgene expression using elements from the DNA tumor virus SV40. The convergent approaches illustrate an interesting dynamic of scientific discovery. Logical, hypothesis-

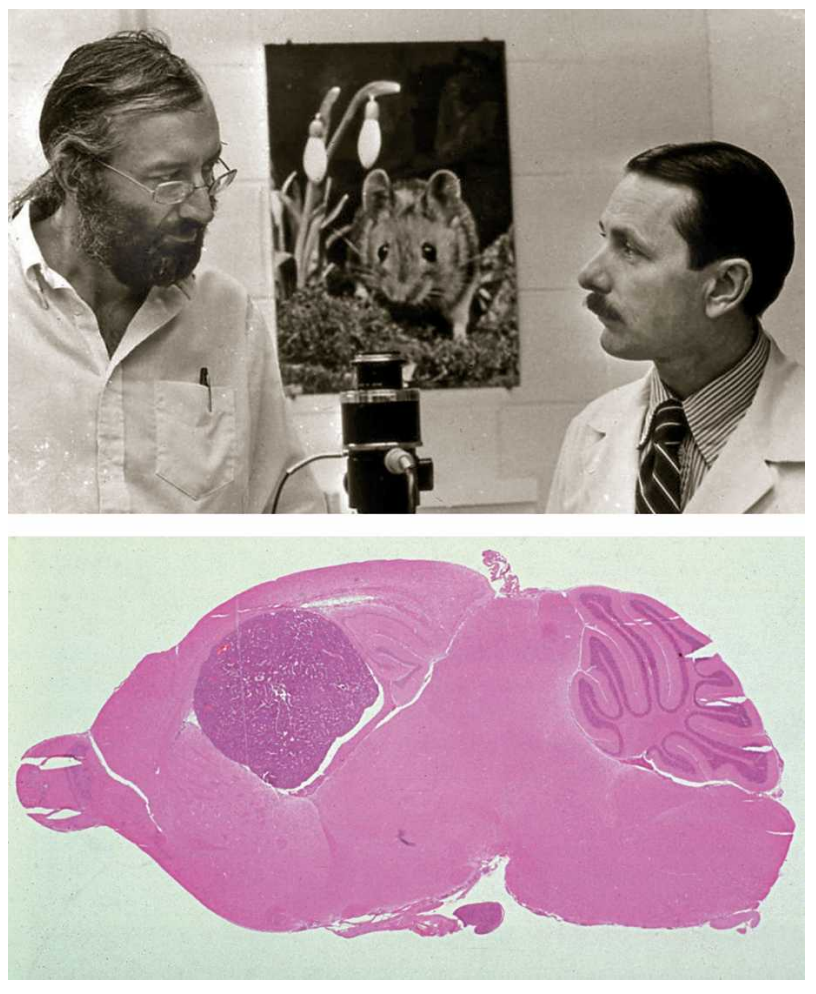

Figure 1. Richard Palmiter, Ralph Brinster, and transgenic mice developing brain tumors. (Top) Palmiter and Brinster are shown at their first meeting in person, in Brinster's office in Philadelphia, in 1981. (Bottom) A brain tissue section (stained with $\mathrm{H} \& \mathrm{E}$ ) from a $S V$-TK transgenic mouse, revealing a large brain tumor mass that was subsequently found to originate from the choroids plexus epithelium in these transgenic mice. (Photographs courtesy of Ralph Brinster.) 
driven research designs, while a tenant of scientific investigation, may in some cases prove intractable due to complex biology and genetics and yet, even in failure, contribute to the investigators' focus and insight into the experimental system. On the other hand, ostensibly unrelated research designs and serendipitous results, in the context of such experience and consideration of a biological question, can produce unexpected progress and knowledge. The two approaches taken by Palmiter and Brinster are elaborated below.

The serendipitous approach: transgenic mice carrying elements of the SV4O DNA tumor virus developed tumors

Buoyed by their success with the $M K$ transgenic mice, Palmiter and Brinster went on to produce transgenic mice expressing rat growth hormone, again under control of the Mt1 gene promoter (the transgene was called $M G H$ ). The result was unusually large mice ("big mice") whose growth rates and body size were clearly enhanced by expression of the transgene-encoded hormone (Palmiter et al. 1982a, 1983). The levels of growth hormone expression from the transgene were, however, unrelated to gene copy number. In an attempt to produce higher and more reliable expression, they began testing transgene constructs that incorporated the SV40 enhancer, reasoning that the small $M t 1$ gene promoter fragment being used was missing an unidentified transcriptional enhancer element. For convenience, Palmiter simply fused the entire SV40 early region-including enhancer, promoter, and coding regions for large and small $\mathrm{T}$-antigens-upstream to the $M K$ or $M G H$ genes such that the SV40 enhancer was adjacent to $M t 1$ gene promoter and the $\mathrm{T}$-antigen genes would be transcribed in the opposite direction. These genes were called $S V-M K$ and $S V-M G H$. It was generally thought at the time that mice were resistant to SV40-induced tumorigenesis, despite the fact that mouse tissue culture cells could be phenotypically transformed by T-antigen. In the summer of 1982, Brinster microinjected the $S V-M K$ construct and generated a number of initial (founder) transgenic mice. Surprisingly, several of the founders died of unknown causes. In December, Brinster and his post-doctoral fellow Howard Chen noted that the cranium of one sickly transgenic mouse had a bulge. That mouse was sacrificed and autopsied, revealing a brain tumor (Fig. 1B). By the next summer, offspring of founder transgenic mice that carried either the $S V$-MK transgene, or the other hybrid gene (SV-MGH), were developing brain tumors (Supplementary Table 1).

Therefore, despite their assumption that the SV40 oncogenes would be inactive as transforming genes in mice, it was evident that inheritance of the SV40 early region predisposed the mice to the development of brain tumors, which were histologically identifiable as originating from the choroid plexus, an epithelial cell layer lining the ventricles of the brain. Additionally, sporadic tumors arose in other organs, particularly the thymus, indicating that the capability to induce tumors was not peculiar to the choroid plexus. In collaboration with
Terry Van Dyke and Arnold Levine, then at State University of New York, Stony Brook, and Albee Messing at the University of Pennsylvania, they went on to assess the hypothesis that the SV40 oncogenes were responsible for the cancer phenotype. This joint effort led to the first published report of a tumor-prone transgenic mouse, published in the journal Cell in June 1984 (Brinster et al. 1984). Subsequent experiments tested transgene constructs containing selected segments of the SV40 enhancer, seeking to identify the regulatory element(s) that were directing expression to the choroid plexus and to determine whether both SV40 large T-antigen and small $t$-antigen oncogenes were responsible for transformation. They found that the SV40 early region's enhancer/promoter and the large T-antigen protein were sufficient to elicit the brain tumor phenotype, whereas the $M K$ gene and the capability to express the SV40 small t-antigen protein were dispensable (Palmiter et al. 1985).

\section{The directed approach: seeking to express cellular oncogenes in transgenic mice}

While mice carrying the SV40 T-antigen gene unexpectedly produced tumors, an experimental design intended to engineer cancer-prone transgenic mice initially failed. Concurrent to the project testing metallothionein-regulated growth hormone transgenes, experiments were initiated in which the $M t 1$ gene promoter was intended to drive expression of the oncogene $\mathrm{V}$-Src. It was well established at that time that retroviruses carrying the $\mathrm{V}$-SrC gene could transform mouse tissue culture cells. They sought to test whether expression of $\mathrm{V}$-Src in mice would lead to proliferative phenotypes, in particular tumors. The $M t 1$ gene promoter was fused to the $V$-Src gene, and the hybrid gene was injected into fertilized eggs. By the fall of 1982, several founder mice carried this transgene (Supplementary Table 1). Not knowing what to expect, they examined founders, as well as transgenic progeny, for tumors and other pathologic abnormalities and assessed mRNA from various tissues and derivative cell lines. Despite considerable effort, and identification of a few sickly transgenic mice, tumors were rare (and not different in frequency than control mice), and there was never a compelling case that any observed pathology was due to what proved to be weak transgene expression. Attempts to improve expression of $M t 1-\mathrm{V}-\mathrm{Src}$ continued for several years, but eventually the project was terminated without publication.

The first successful attempt at rational design of an oncomouse was conceived when Palmiter traveled to Australia to attend a meeting in February 1984. After giving a seminar in Melbourne, where he mentioned the development of tumors in mice bearing SV40 T-antigen, Jerry Adams and Suzanne Cory of the Walter and Eliza Hall Medical Institute (WEHI) proposed testing the Myc gene, either as a $M t 1-M y c$ transgene for broad expression, or with an immunoglobulin enhancer $(E \mu)$ juxtaposed to the $M y c$ gene, in a construct meant to recapitulate the chromosomal translocation seen in certain human B-cell lymphomas. The Mt1-Myc and Ep-Myc genes were in- 
jected into fertilized eggs later that summer (Supplementary Table 1). The Mt1-Myc mice failed to develop tumors or evidence other pathologies (in zero of 23 founders), perhaps as a result of linked plasmid vector sequences, and were not bred or further analyzed. Excitingly, and in marked contrast, the Ep-Myc transgenic mice proved to be tumor prone: They reliably developed pre-B-cell and mature B-cell lymphomas (Adams et al. 1985), supporting the causality of Ig-Myc translocations as an oncogenic event in the human malignancies. Finally, their hypothesis-driven approach to express a cellular oncogene in transgenic mice, conceived in 1981, had succeeded.

Subsequently, Palmiter and Brinster began using other cell-specific promoters to regulate the expression of various oncogenes. When David Ornitz joined the Palmiter laboratory in 1984, they began using the Elastase gene promoter to control expression of SV40 T-antigen in pancreatic acinar cells. Those mice reliably developed acinar cell (exocrine pancreatic) tumors in a heritable manner (Ornitz et al. 1985, 1987). Later, the same promoter was used to drive expression of either a wild-type Ras gene (now called Hras1) or activated versions thereof containing mutations that enhanced its functional activity. The activated Ras gene was effective at eliciting acinar cell transformation and pancreatic tumorigenesis, which was initiated during fetal development (Quaife et al. 1987).

Thus, while serendipity produced the first oncomouse in 1982, the concept of using cellular promoters and enhancers to deliberately regulate oncogene expression eventually paid off.

\section{Subsequent studies with T-antigen and Myc}

These early oncomice (as well as those described below) helped solidify the causality of oncogenes and the utility of genetically engineering transgenic mice for studying genes implicated in cancer. Beyond that proof of principle, several of these original models have been productively studied over the years, producing remarkable new knowledge. Terry van Dyke-involved in the characterization of the first oncomouse, the $S V-M K$ model of brain cancer-used it as a foundation for her subsequent research program at the University of North Carolina. She and her colleagues dissected the requirements and roles of the $\mathrm{p} 53$ and $\mathrm{Rb}$ tumor suppressor proteins as barriers to de novo carcinogenesis, as revealed by the capability of the T-antigen oncoprotein (and selected fragments thereof) to abrogate each of their functions, thereby enabling hyperproliferation, suppression of apoptosis, and consequent tumor progression (Chen et al. 1992; McCarthy et al. 1994; Symonds et al. 1994).

The En-Myc lymphoma model continues to be studied to this day and has produced a wealth of important knowledge. For example, Cory and Adams went on to show that $M y c$ promoted proliferation and blocked differentiation of developing B lymphocytes, and that the En-Myc mice showed a premalignant phase much as is evident in the human disease, implying that the oncogene was necessary but not sufficient to dictate the lym- phoma phenotype (Langdon et al. 1986). Then they and their WEHI collaborators, David Vaux and Andreas Strasser, went on to discover that proliferation-inducing oncogenes such as $M y c$ require counterbalancing suppression of apoptosis, a cell death process that otherwise attenuates proliferative expansion of $M y c$-expressing cells; they in particular demonstrated the synergistic effects of up-regulating the anti-apoptotic factor Bcl-2 (Vaux et al. 1988; Strasser et al. 1990). These studies were crucial to the emerging realization that suppression of apoptosis was a key "hallmark" capability of cancer. They continued to use this model to further elucidate the interplay of apoptotic regulators with oncogenes in lymphoid tumorigenesis (e.g., see Egle et al. 2004; Kelly et al. 2007). Several groups used the En-Myc oncomice to demonstrate the functional importance of Arf-p53 circuit as a tumor suppressor, whose loss of function also attenuated apoptosis in Myc-expressing lymphoid cells, facilitating hyperproliferation and tumorigenesis (Eischen et al. 1999; Jacobs et al. 1999; Schmitt et al. 1999).

Anton Berns of the Netherlands Cancer Institute and Jerry Adams independently used the E $\mu-M y c$ model as a platform for insertional mutagenesis screens to identify cooperating oncogenes and tumor progression factors, which led to the discovery of a number of important regulatory genes, including Bmi-1 and Pim-1 (Haupt et al. 1991; van Lohuizen et al. 1991), two genes that have proven to be involved in stem cell homeostasis as well as tumorigenesis. The $E \mu-M y c$ model has also been insightfully applied to experimental therapeutics, assessing mechanisms and determinants of chemo-sensitivity and chemo-resistance to therapies aimed at lymphoid malignancies, and revealing genetic heterogeneity in the tumor cell population as a factor in acquired resistance (Schmitt et al. 2000, 2002; Wendel et al. 2004). Recently, Scott Lowe and colleagues at Cold Spring Harbor Laboratory (CSHL) demonstrated the utility of RNA interference as a tool to probe gene functions during development of lymphoid cancers in En-Myc mice (Hemann et al. 2003), heralding the future application of this breakthrough technology to mechanistic studies in mouse models of other human cancer types. Remarkably, these are just a few examples of the applications and knowledge produced over the past 20 years using a first-generation model originally designed to test a simple hypothesis: that the chromosomal translocations leading to juxtaposition of immunoglobulin and Myc genes could cause cancer.

Unbeknownst to Palmiter and Brinster and their colleagues, three other groups were pursuing similar ideas in the early 1980s that were directed toward making mouse tumor models using transgenic technology, as elaborated below.

\section{Phillip Leder and Timothy Stewart: transgenic mouse models of breast cancer}

Timothy Stewart helped establish transgenic methodology as a post-doctoral fellow with Beatrice Mintz at the Fox Chase Cancer Center in Philadelphia. In 1982 he 
decided to continue his post-doctoral training with Phillip Leder at Harvard Medical School. (Fig. 2A). He brought with him the expertise in generating transgenic mice by pronuclear injection of fertilized mouse eggs, developed working in collaboration with Erwin Wagner, another post-doctoral fellow in the Mintz laboratory (Wagner et al. 1981; Stewart et al. 1982), as described further below. He came to learn molecular biology with Leder, who was one of the pioneers in molecular cloning and structural analysis of mammalian genes. The Leder laboratory had characterized the chromosomal transposition that fused the $M y c$ proto-oncogene with immunoglobulin gene regulatory regions in Burkitt's lymphoma, creating natural hybrid genes that redirected $M y c$ gene expression to a specific cell type, the B lymphocyte, evidently evoking lymphoid cancer. Rather than recapitulating the Immunoglobulin-Myc chromosomal translocation as a hybrid gene in transgenic mice (as Palmiter, Brinster, Cory, and Adams did in generating their Ep$M y c$ mice), Stewart and Leder decided to create a differ-
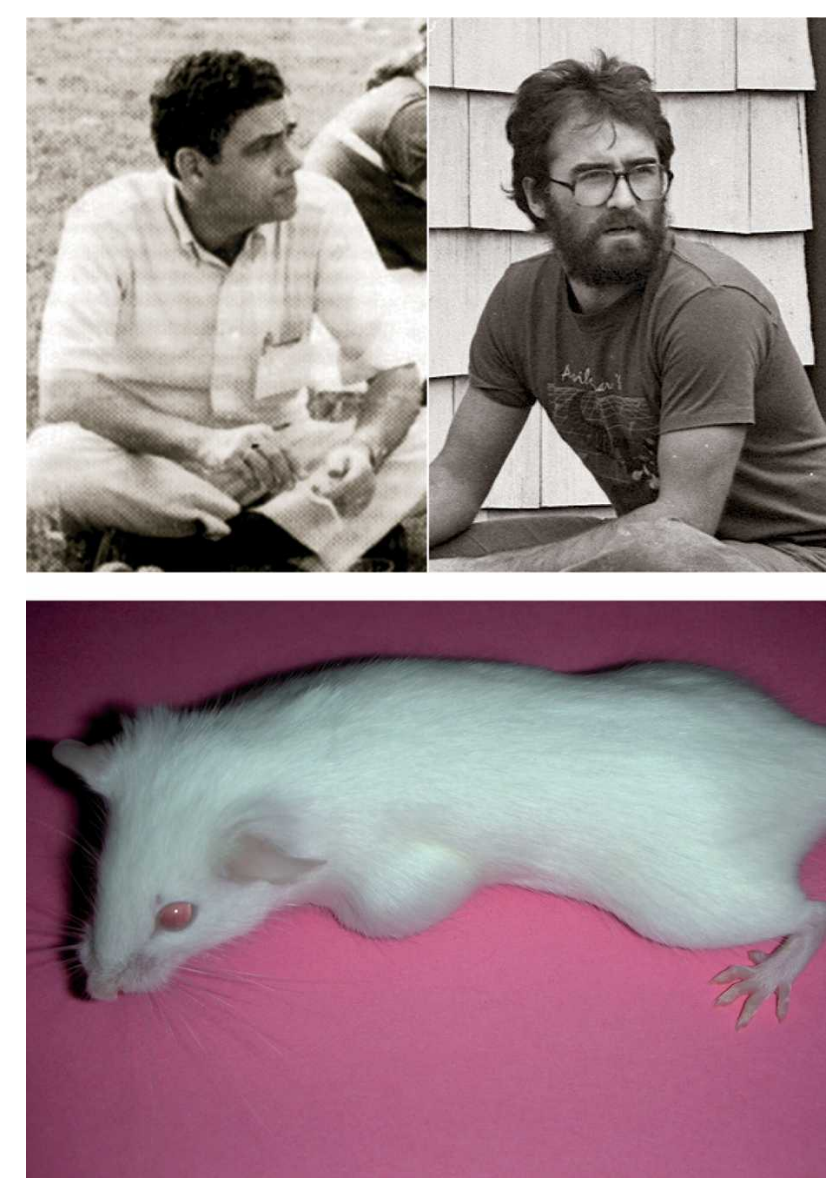

Figure 2. Phil Leder, Tim Stewart, and the first transgenic mouse model of breast cancer. (Top) Phil Leder (left) and Tim Stewart (right) at CSHL in 1983 and 1984, respectively. (Photographs courtesy of Cold Spring Harbor Laboratory Archives). (Bottom) A female MMTV-oncomouse with a protuberant breast tumor, illustrative of the tumors that Stewart and Leder observed in their groundbreaking studies. (Photograph courtesy of Douglas Hanahan and Mikala Egeblad.) ent hybrid gene, with the clear aim to develop a mouse model of breast cancer. A retrovirus, called MMTV (for mouse mammary tumor virus), was known to cause mammary tumors in certain strains of mice, and its regulatory region had been mapped. Gordon Hager, a former colleague of Phil Leder from his days at the National Institutes of Health (NIH), had shown that when the MMTV LTR was fused to another oncogene, the viral Ras gene, its expression was regulatable by steroid hormones in cultured mammalian cells (Huang et al. 1981). Hager's work illustrated the possibility of using the MMTV LTR to control oncogene expression in a hormone-dependent fashion. The unanswered question was whether the MMTV regulatory region was sufficient to confer tissue-specific gene expression and hormone inducibility on an oncogene in the mammary gland of a transgenic mouse. Stewart and Leder aimed to find out.

Tim Stewart constructed a series of hybrid genes in which the MMTV LTR was fused to the Myc coding region, and then preceded to microinject the DNA into mouse embryos, likely in early 1983. Thirteen lines of transgenic mice were established. Initially there was no phenotype, which might have been taken as failure, but Stewart and Leder persisted, successively breeding female $M M T V-M y c$ transgenic mice and monitoring them as they aged. Their patience and persistence were rewarded: Mammary tumors began to appear after the second or third pregnancy in the female founders of two of the 13 lines and, in turn, in their female progeny (Supplementary Table 2). Tumors typically arose in only one or a few of the 10 mammary glands (Fig. 2B). The temporal latency and the development of tumors in a subset of the 10 mammary glands together argued that $M y c$ was necessary but insufficient to evoke breast cancer. The data supported both the causality of oncogenes as cancer-inducing agents and the notion, inferred from cancer epidemiology, that tumorigenesis typically involves multiple functional aberrations in cells and tissues, some apparently not conferred by $M y c$.

The successful development of the MMTV-Myc mouse model of breast cancer was enabled by the complementary expertise and knowledge of the Leder laboratory in molecular biology and of Tim Stewart in transgenic mouse technology. Tim had also brought nascent ideas developed in discussions with Erwin Wagner (in the Mintz laboratory) about putting oncogenes into mice. In October 1984, Stewart and Leder published their report on this genetically engineered mouse model of breast cancer, subsequently dubbed "oncomice" (Stewart et al. 1984).

A follow-up study focused on one line of MMTV-Myc mice that showed broader expression in multiple tissues, likely a result of the random chromosomal position of transgene integration (Leder et al. 1986). They reported that $M y c$ could elicit neoplasms in some but not of all organs in which its expression was up-regulated, including, in addition to the mammary epithelium, the testes and the hematopoietic system (B and $\mathrm{T}$ lymphocytes, and mast cells). The results suggested that some cell types were more vulnerable to the action of specific on- 
cogenes, a conclusion that was also forthcoming from the studies of Palmiter and Brinster and of Wagner. The Leder laboratory then went on to develop mice similarly expressing a viral Ras oncogene ( $\mathrm{v}-\mathrm{Ha}$-Ras) under control of the MMTV regulatory region to assess its capability to elicit tumors when overexpressed in transgenic mice. They found that activated Ras was indeed an oncogene in transgenic mice, wherein it induced multiple neoplasms, of the Harderian lacrimal gland, the breast, the salivary gland, and lymphoid cells. They went on to demonstrate "oncogene cooperation" of Ras and Myc, a result initially demonstrated in transfected cells (Land et al. 1983), by crossing the MMTV-Myc and MMTV-V-HaRas mice. The double transgenic mice displayed a significant acceleration in the time course of tumorigenesis in most of these organs (Sinn et al. 1987). The tumors were in general still focal (stochastic) within the affected organs (as they were with Myc or Ras alone), suggesting that additional "secondary events" were still necessary to elaborate the tumors, an implication common to virtually all of the oncomice discussed herein or produced subsequently, and consistent with the epidemiology implicating multihit tumorigenesis in most human malignancies.

\section{Continuing studies with the MMTV-Myc and -Ras oncomice}

The enduring knowledge from the original MMTV-Myc and $M M T V$-Ras transgenic mice includes the realization that the mammary epithelium is quite sensitive to malignant transformation by oncogenes leading to breast cancer. Additionally, these models demonstrated necessity but not sufficiency of these two prominent oncogenes, even when combined, as evidenced by the temporal latency and focality of tumor development in a subset of the 10 mammary glands in the mouse, which helped cement the hypothesis that tumorigenesis is multistep process, involving stochastic changes above and beyond those instructed by the oncogenes.

The focus of breast cancer research in mice has largely shifted to second-generation models involving different oncogenes and knockouts of tumor suppressor function (Evers and Jonkers 2006; Ursini-Siegel et al. 2007; see also the Mouse Models of Human Cancer Consortium Web site [http://emice.nci.nih.gov/emice/mouse_ models/organ_models/mammary_models], in particular Tables 1 and 2 therein). Nevertheless, Leder and Stewart's original oncomice continue to be studied. For example, the $M M T V-M y c$ and MMTV-Ras oncomice have in this decade been used in genetic crosses that revealed tumor-promoting versus antagonistic interactions between the cell cycle inhibitor (and putative tumor suppressor) p21 and the Myc and Ras oncogenes, respectively (Bearss et al. 2002), presenting a mechanistic rationale for cooperation of the Ras $+M y c$ oncogene in mammary carcinogenesis. In another recent study (Ray et al. 2007), the MMTV-Ras + Myc oncomice were used to document the functional importance of another cell cycle regulator, the cell cycle-stimulating phosphatase CDC25A: Genetically elevated expression of CDC25A in double transgenic mice accelerated mammary tumorigenesis, supporting the significance of up-regulated expression of CDC25A in human cancers. The MMTV-Ras and MMTV-Myc (and Ras $+\mathrm{Myc}$ ) oncomice have also been used to study responses to chemotherapy, revealing significant differential efficacy as a function of the oncogene(s) driving tumorigenesis (Bearss et al. 2000), a result with implications for tailoring effective treatment of human breast cancer.

\section{Erwin Wagner: bone tumors in transgenic mice expressing the Fos oncogene}

From 1979 to 1982, Erwin Wagner (Fig. 3A) worked closely together with Tim Stewart in Beatrice Mintz's laboratory at the Fox Chase Cancer Center in Philadelphia, developing new tools for transferring genes into the germline of mice (Wagner et al. 1981; Stewart et al. 1982). Wagner's intuition about studying the function of cellular proto-oncogenes and viral oncogenes in mice evolved during regular discussions with Tim Stewart that began in the Mintz laboratory and continued after Stewart joined Phil Leder's laboratory during the summer of 1982. In the course of several meetings in 1982 and early 1983 between Stewart and Wagner (then in Boston and Philadelphia, respectively), they elaborated specific ideas and strategies for engineering oncomice. The ideas and implications for generating mice that expressed oncogenes in a specific organ-e.g., the mammary gland-or more broadly in most organs of transgenic mice, seemed obvious to them and only a matter of being able to engineer transgenic mice that efficiently (and sufficiently) expressed an oncogene in the targeted $\operatorname{organ}(\mathrm{s})$.

At a meeting at the Salk Institute in summer of 1982, Wagner met Rolf Müller, who was studying the Fos oncogene at the biochemical and molecular levels. Fos was first discovered as a viral oncogene (as were Src and $M y c$ ) carried by the FBJ and FBR retroviruses, which elicited bone tumors following infection of mice. Müller and Wagner both decided to join the newly established Differentiation Program at the European Molecular Biology Laboratory (EMBL) in Heidelberg, Germany, and it seemed logical to join forces and work together to investigate the roles of c-Fos in mouse development, tissue homeostasis, and disease, by using transgenic mouse technology. A research proposal was submitted to EMBL in the fall of 1982 by Wagner and Müller, in which they proposed to work jointly on studying the roles of cellular proto-oncogenes and activated (viral) oncogenes in transgenic mice, beginning with over- and misexpressing the Fos proto-oncogene to assess its capability to act as a cancer-causing oncogene. The prospect of similarly investigating other cellular proto-oncogenes and viral oncogenes such as Src and Myc was also mentioned. In mid 1983, Wagner moved to the EMBL and focused his research efforts on the by then trendy oncogenes.

Wagner sought to establish three experimental systems to study oncogene function by gene transfer: transgenic mice, embryonic stem (ES) cells, and hematopoi- 

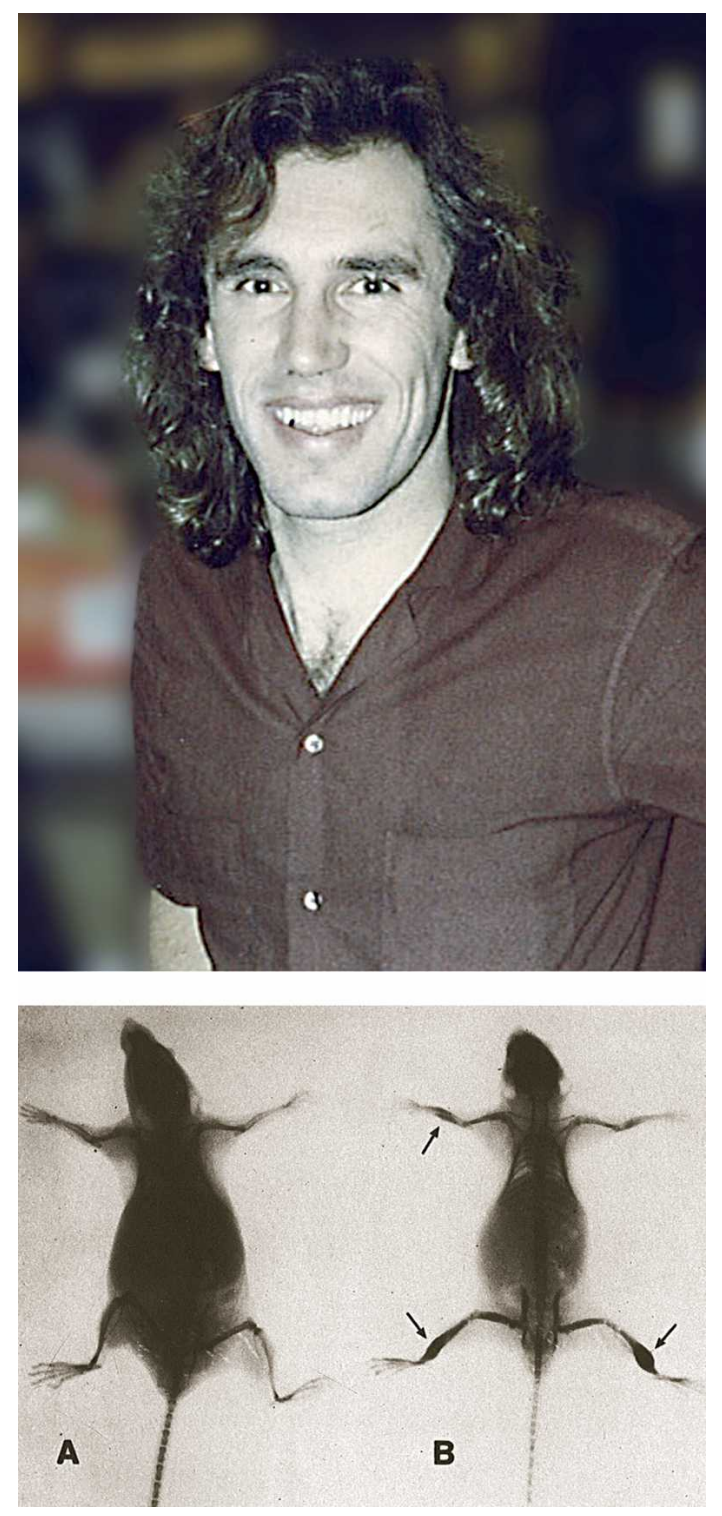

Figure 3. Erwin Wagner and a mouse model of bone cancer. (Top) Erwin Wagner in 1981 in Philadelphia, during the period when he and Tim Stewart were brainstorming about engineering oncomice. (Bottom) An X-ray of the bones in a normal mouse (left) and in a Fos transgenic mouse (right), which has multifocal bone tumors resultant to expression of the Fos oncogene. (Photographs courtesy of Erwin Wagner.)

etic stem cells (Wagner 1990). He reasoned that the distinctive systems would each be instructive about the biological functions of oncogenes. By early 1984, Wagner had set up the transgenic mouse technology at the EMBL, and embryo microinjections with plasmids carrying Fos constructs began in June 1984. The initial studies on Fos in transgenic mice were performed together with Uli Rüther, Wagner's first post-doctoral fellow. Their first transgenic mouse was born in early July 1984. The transgene (MT-Fos) was composed of the normal mouse cellular Fos gene under the control of the inducible human metallothionein-2 (MT2A) promoter (ob- tained from Michael Karin, another alumnus of the Mintz laboratory) with the translation start and stop codons as well as the polyA transcriptional termination signal derived from the natural Fos gene. Unfortunately, multiple independent lines of transgenic mice failed to express Fos at appreciable levels.

After several unsuccessful attempts to improve Fos expression with modified transgenes (Supplementary Table 3), a breakthrough came when Wagner and Rüther replaced the $3^{\prime}$-untranslated region of the natural c-Fos gene with an LTR from FBJ murine sarcoma virus (MTFosLTR). They reasoned that this regulatory element might stabilize the Fos mRNA transcript and possibly confer mesenchymal specificity due to the tropism of the FBJ virus. Transgenic mice carrying this revamped hybrid gene were born in early 1985 (Supplementary Table 3) and were found to express Fos in multiple tissues. The mice had a reproducible phenotype-namely, perturbations in bone development during embryogenesis. Moreover, as the mice aged, hyperproliferative bone lesions arose that, however, did not progress to tumors during the 10 -mo period they were initially monitored. Wagner's first study on the consequences of up-regulating Fos expression on bone development in transgenic mice was published in January 1987 (Rüther et al. 1987). Rüther and Wagner went on to replace the metallothionein promoter with the mouse MHC Class I (H2) promoter, seeking to broaden and possibly enhance the expression pattern. Two founder mice carrying the H2FOSLTR construct developed multiple bone tumors at 6-7 mo of age (Fig. 3B); while these mice did not sire lineages, they implicated Fos as a bona fide oncogene outside of the context of the RNA tumor virus in which it was originally discovered. Buoyed by these results, Wagner and Rüther went on to systematically monitor large cohorts of mice from the original MT-FOSLTR lines over a period of 1-2 years; they found that osteosarcomas consistently developed, establishing Fos as an oncogene, one with a propensity for inducing bone tumors (Rüther et al. 1989). Thus an experimental design crafted in the early 1980s to assess the oncogenic potential of the FOS proto-oncogene and its viral homologs finally reached fruition 7 years later, producing tumors as Wagner and colleagues had envisioned.

\section{Subsequent studies with mice expressing Fos}

The osteosarcoma-prone Fos transgenic mice became a valuable research tool in Wagner's subsequent research, aiming to clarify the remarkable specificity of the transforming function of Fos when compared with other AP-1 family members such as Jun, Jun-B, Fra-1, and Fra-2. For example, the Wagner group demonstrated that Jun has a cooperating function in osteosarcoma development, in that Fos and Jun double transgenic mice yielded more aggressive bone tumors. Remarkably, despite widespread expression in multiple tissues, the tumors were still confined to the bone/osteoblast compartment, further substantiating the selective capability of Fos to transform osteoblasts (Wang et al. 1995). In another line of inves- 
tigation, they showed that engineered loss of the p53 and $R b$ genes in the context of overexpressing the Fos oncogene increased tumor burden (Jochum et al. 2001; W. Jochum and E.F. Wagner unpubl.), helping to generalize the functional importance of these tumor suppressors as barriers, in particular to bone tumor growth. Wagner's original oncomice are still being used to further define the transforming function of FOS (David et al. 2005) and its involvement in a regulatory network governing osteoblast proliferation and function in the regulation of bone mass-parameters of biomedical importance for developing strategies to counteract degenerative bone diseases such as osteoporosis.

\section{Douglas Hanahan: transgenic mice developing pancreatic islet and skin tumors}

In another convergence, Douglas Hanahan (Fig. 4A) engineered several of the first oncomice at CSHL on Long Island, New York. While completing his graduate studies at Harvard University, Hanahan spent some of his time performing research in the James building at CSHL, which was a hotbed of tumor virology. DNA tumor viruses such as SV40 and adenovirus were being used to unravel basic principles of DNA transcription and replication, cell transformation, and oncogenic transformation. Initially, Hanahan became enthused about using DNA tumor virus vectors in combination with new mammalian cell transfection methods to selectively immortalize and/or transform primary cell types. The insulin-producing pancreatic $\beta$ cell was such a cell type whose defining gene had been cloned and its core regulatory sequence defined. The rat insulin gene was acquired from Walter Gilbert at Harvard, and combined in several configurations with the SV40 early region, producing the RIP1-Tag and RIR-Tag (reverse promoter) recombinant genes. The logic in choosing the SV40 early region included the possibility of inducing proliferation or tumors in the cell types expressing the genes, as well as the prospect of using antibodies against $\mathrm{T}$-antigen to detect its expression.

The aforementioned demonstrations that foreign genes could be transferred into the mouse germline and expressed in lines of transgenic mice (for review, see Palmiter and Brinster 1986) inspired Hanahan to adopt transgenic mouse technology, as it seemed to him a more elegant means to study gene regulation and function, in the context of a whole animal. With the support of James Watson and Joseph Sambrook at CSHL, Hanahan purchased the microscopes and microinjection equipment in early 1983 and spent several weeks learning the methodology from Elisabeth Lacy at Memorial Sloan Kettering Cancer Center in New York City. After defending his thesis, Hanahan moved to CSHL to start making transgenic mice. The RIP1-Tag and RIR-Tag genes were on the top of the list.

A heated debate within the James laboratory at CSHL (and in the larger cancer research community) was about whether the viral oncogenes carried by SV40 and adenovirus were somehow artifactual, given that these viruses did not produce tumors in their natural hosts. This de-
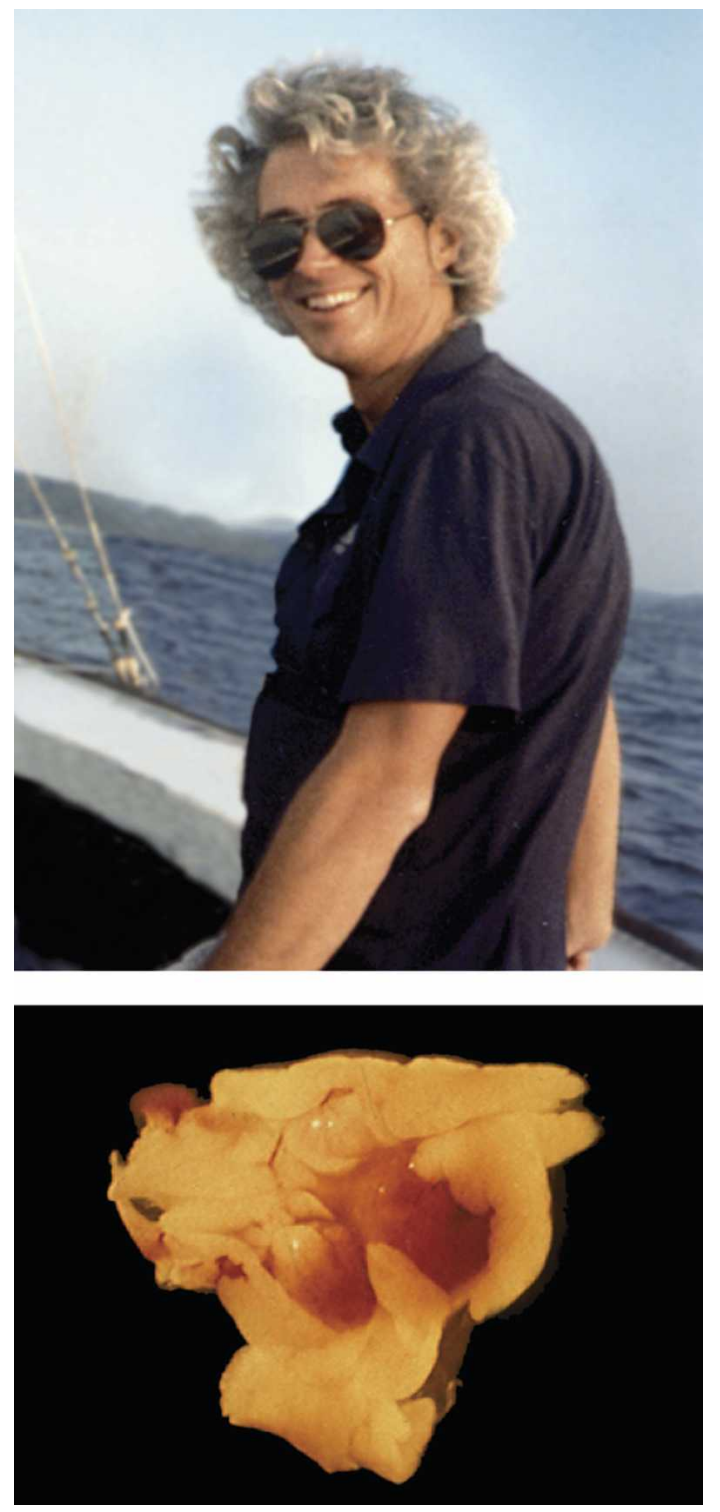

Figure 4. Douglas Hanahan and a mouse model of pancreatic cancer. (Top) Douglas Hanahan sailing on Cold Spring Harbor in 1986, near the laboratory where he first engineered oncomice. (Bottom) The pancreas from a RIP-Tag2 transgenic mouse, with several highly vascularized (red) tumors in the pancreas, originating from the insulin-producing islet $\beta$ cells. (Photographs courtesy of Douglas Hanahan.)

bate came before these oncogenes were shown to inactivate the p53 (Trp53) and retinoblastoma (Rb1) tumor suppressor genes, thereby linking them to central mechanisms of cellular transformation. A related class of DNA tumor viruses, the papillomaviruses, was more causally linked to cancers in their native hosts. Michael Botchan, Peter Howley, and others had embraced bovine papillomavirus (BPV) as a model both for DNA replication and for studying the transforming effects of the human papillomaviruses; BPV-1 could both replicate in and transform mouse cells. This viral genome seemed like a good one to assess the relevance of DNA tumor viruses 
to cancers. If BPV could elicit tumors in transgenic mice, that result would strengthen the argument that DNA tumor viruses were indeed agents of cancer. Thus, the BPV genome was added to Hanahan's initial list of genes to be introduced into mice.

\section{Pancreatic islet tumors in RIP-Tag and RIR-Tag transgenic mice}

In late 1983, Hanahan began to master the embryology of making transgenic mice. In February 1984, a mouse born from embryos injected with the reverse promoter $R I R$ Tag construct was shown to carry the gene and was set up to breed. A few months later a jackpot litter was born, in which four of seven pups contained the RIP1-Tag transgene. Each of these founder mice was set up to breed, with the hope of establishing lines of transgenic mice. Meanwhile, first RIR-Tag transgenic mouse died at 9 wk of age, shortly after giving birth; her pups were fostered, and $50 \%$ of them carried the RIR-Tag transgene. The transgenic progeny also died at 9 wk of age, with evident red nodules in the pancreas. A few months later, one of the mice carrying the RIP1-Tag transgene also died in late-stage pregnancy; she was also 9 wk old. Her female sibling died a few weeks later after bearing a litter; she was 12 wk old (Supplementary Table 4). Both of these transgenic mice had red nodules in their pancreas (Fig. 4B). The pups of the latter mouse survived, establishing the RIP1-Tag2 line. In the early generations, all the transgenic mice in this line died at $9-10$ wk of age, and it was only by rapid breeding of male transgenic mice that the line was preserved. The sudden death proved to be the result of hyperinsulinemia and consequent hypoglycemic shock. In retrospect, this was a predictable result of inducing tumors of the insulin-producing $\beta$ cells.

The other two initial RIP1-Tag founder mice were males and mosaic, and it took several litters to transmit the RIP1-Tag transgene, which subsequently segregated at Mendelian frequencies, establishing the RIP1-Tag3 and RIP1-Tag4 lines. In contrast to the rapid onset of pancreatic tumors and early death seen in their other transgenic siblings (and the RIP-Tag2 progeny), the founders and their progeny of these transgenic mice (RIP-Tag3 and RIP-Tag4) did not die quickly. Eventually, however, every mouse inheriting a RIP1-Tag transgene in these lines also died, again with red tumor nodules in the pancreas. Thus all four mice born in this jackpot litter died of tumors that were subsequently confirmed to be insulinomas and islet cell carcinomas, having arisen from expression of the SV40 early region in the insulin-producing $\beta$ cells. Similarly, mice originating from the founder carrying the reversed promoter construct, RIR-Tag, also developed pancreatic islet $\beta$-cell tumors and succumbed as a consequence.

Hanahan first reported on the cancer phenotypes of the RIP1-Tag and RIR-Tag transgenic mice at a CSHL Banbury Conference on "Genetic Manipulation of the Mammalian Ovum and Early Embryo," held in October 1984. Ralph Brinster and Tim Stewart each presented their data describing transgenic mice that developed brain and breast tumors, respectively. Thus, by the fall of 1984, it was evident that both SV4O T-antigen and Myc could induce cell-specific tumors in transgenic mice. Hanahan's results describing transgenic mice with organ-specific, multistage cancer phenotype were published the next year (Hanahan 1985).

\section{Skin tumors in BPV transgenic mice}

In parallel to the RIP-Tag microinjections, a transgenic mouse carrying a partial tandem repeat of the BPV-1 genome (termed BPV1.69) was born in February 1984. The $B P V 1.69$ founder and its transgenic progeny were normal and showed no early signs of disease. The BPV1.69 transgenic mice were left in a back rack in the CSHL animal care facility. Then, at more than a year of age, during the spring of 1985 , the founder and his first-generation progeny began to develop skin abnormalities and then protuberant tumors, later shown to be dermal fibrosarcomas. Notably, $B P V$-associated tumors in cattle were typically composed of dermal fibroblasts and epidermal keratinocytes. Thus the viral genome in a transgenic mouse was recapitulating part of its natural oncogenic specificity, supporting the causality of DNA tumor viruses and the utility of transgenic oncomice. The skin tumor phenotype of the BPV1.69 transgenic mice was reported in 1986 (Lacey et al. 1986).

This study set an example (as did the MMTV-Myc and MT-FOSLTR mice) of tumors arising heritably but after a long latency in transgenic mice. Although the founder was born a few weeks before the RIP1-Tag2 founder, the mice developed obvious tumors at 15 mo instead of at 3 mo. The time course of tumor development and the focal nature of the tumors that arose in the BPV1.69 transgenic mice again supported the developing consensus that activation/expression of oncogenes was necessary but not sufficient to induce formation of tumors in a spectrum of organs and cell types. Consistent with the epidemiology and histopathology of many human cancers, the latency suggested the necessary of cooperating (secondary) events during multistep tumorigenesis.

In congruent efforts, the Hanahan and Wagner groups each produced transgenic mice designed to broadly express another viral oncogene, the Polyomavirus middle- $T$ $(P y m T)$ oncogene, aiming to assess its effects on different cell types and tissues. Both groups found that the PymT oncogene induced benign tumors of the vascular endothelium-hemangiomas - indicative of a particular sensitivity of endothelial cells to the actions of this oncoprotein (Bautch et al. 1987; Williams et al. 1988). The PymT oncogene was not specific for this cell type, however, as illustrated by its remarkable potency in eliciting metastatic breast cancer in MMTV-PymT transgenic mice, developed by William Muller (Guy et al. 1992), a former post-doctoral fellow in Phil Leder's laboratory.

\section{Subsequent insights from RIP-Tag and BPV oncomice}

Among the early oncomice engineered by Hanahan, the RIP-Tag lines of mice have proved to be an enduring 
model system. The differential latencies of tumorigenesis in the initial lines led to early studies on the establishment of immunological self-tolerance to transgenic antigens (Adams et al. 1987) and in turn to the discovery of rare "peripheral antigen-expressing" (PAE) cells in the thymus that expressed the endogenous insulin and other organ-specific genes (Jolicoeur et al. 1994; Smith et al. 1997). The RIP1-Tag2 model was used in collaboration with Judah Folkman, a pioneer of angiogenesis research, to show that induction of angiogenesis was a discrete, rate-limiting event, involving an angiogenic switch activated during premalignant stages of multistep tumorigenesis (Folkman et al. 1989; Hanahan and Folkman 1996). Subsequent investigations of the angiogenic switch in this model have revealed roles for matrix degrading enzymes, supplied by immune inflammatory cells, in activating an angiogenesis inducer, the vascular endothelial growth factor VEGF (Bergers et al. 2000; Joyce et al. 2004, 2005; Nozawa et al. 2006). The importance of pericytes in supporting the integrity of the tumor vasculature was revealed in studies using the RIPTag2 line (Bergers et al. 2003). Provocatively, disruption of pericyte association with the tumor vasculature has recently been shown to facilitate otherwise rare bloodborne metastasis in this model (Xian et al. 2006).

In other applications, genetic studies involving crosses of RIP-Tag2 to gene knockout mice demonstrated that insulin-like growth factor 2 (IGF-2) was involved in suppressing p53-independent apoptosis, which otherwise severely attenuated malignant progression (Christofori et al. 1994). Furthermore, Gerhard Christofori and colleagues used the RIP-Tag2 model to demonstrate that loss of the cell adhesion molecule E-cadherin was causal for malignant progression to invasive carcinomas (Perl et al. 1998), solidifying a hypothesis raised by descriptive studies in human cancers. Finally, the RIP-Tag model has been established as an innovative platform for experimental trials of mechanism-based therapeutic drugs. For example, one recent study has implicated a new mechanism of "evasive resistance" to angiogenesis inhibitory drugs targeting the VEGF signaling pathway, involving activation of other proangiogenic inducers that can evidently substitute for VEGF signaling so as to sustain tumor angiogenesis (Casanovas et al. 2005). Collectively, these citations illustrate the unpredicted and enduring value of this prototypical model as a research tool, above and beyond its role in establishing proof of principle that oncogenes can cause cancer when expressed in a mammalian organism.

While the multistage pathway to dermal fibrosarcoma in the $B P V$ transgenic mice was studied and parameters of tumor progression identified (e.g., Bossy-Wetzel et al. 1992), the model did not endure: The tumor phenotype slowed and eventually disappeared as the transgene was passed to successive generations. Hanahan's focus on papillomaviruses persisted, however, shifting to engineer mice that modeled the actions of human papillomavirus oncogenes on epithelia. Transgenic mice developing squamous cell carcinomas of the skin and cervix were generated, and their continuing investigation has produced new knowledge; for example, in substantiating the counterintuitive capability of the immune system to functionally enhance tumor progression, in part by upregulating tumor angiogenesis (Coussens et al. 2000; Giraudo et al. 2004; de Visser et al. 2005).

Collectively, the convergent results of these four parallel efforts substantiated the principle that transgenic mice could be engineered to express oncogenes that elaborated the development of tumors, confirming and substantiating both the causality of oncogenes and their insufficiency, presenting clear opportunities to investigate mechanisms of multistep tumorigenesis.

\section{A distinctive impact: patenting the oncomouse technology}

Another notable aspect to the history of tumor-prone transgenic mice involves patents issued by the US government to Harvard University on the production and use of oncomice, based on the work of Tim Stewart and Phil Leder. At the time, the idea of patenting intellectual property related to biological processes was gaining prominence at academic institutions. This ascendance of intellectual property in biology was inspired by the biotechnology revolution, which was opening up extraordinary frontiers in biomedical research and drug development, for elucidating molecular mechanisms of disease states and devising drugs designed to ameliorate them. Moreover, the US Congress in 1980 had passed a law, the Bayh-Dole Act, that encouraged academic institutions to patent and transfer technology to industry involving discoveries made under the auspices of research funded by the US government. Thus, in the early 1980s, the notion of patenting material discoveries and new concepts arising from academic research was percolating slowly through the biomedical research community, which likely helped motivate the decision by Harvard to file patents based on Leder and Stewart's oncomice.

The first of three patents broadly claiming oncomice as an invention was submitted by Harvard University on June 22, 1984, about the same time that the Brinster et al. (1984) study was published in Cell. Notably, Palmiter and Brinster did not consider patenting their discovery. The first Harvard patent was issued in 1988 (Leder and Stewart 1988), broadly claiming "a transgenic nonhuman animal whose germ cells and somatic cells contain an activated oncogene." Two continuation patents on oncomouse technology and its applications were subsequently issued (Leder and Stewart 1992, 1999). The 1992 patent claimed the derivation and use of cell lines from tumor-bearing oncomice, while the 1999 patent described the use of oncomice as platforms for testing both tumor-promoting carcinogens and anti-cancer drugs. All three patents were exclusively licensed by Harvard University to the Dupont Corporation, which at the time was sponsoring research in Phil Leder's laboratory. The original 1988 patent expired in 2005, while the other two remain in force.

A conceptual rationale for governments issuing patents is to provide some protection from competition and 
thus motivate patent holders and their licensees to take the financial risks involved in developing ideas into products that in turn benefit its citizens. Dupont, however, has not obviously sought to generate or import oncomice so as to use them in its internal drug development programs. Rather, Dupont has focused on sublicensing the Harvard patents, with hefty fees and restrictions, to industry (and in some cases to academic institutions), authorizing such institutions to engineer, obtain, and/or use oncomice for research and for preclinical testing of investigational drugs with promise for improving the treatment of human cancer. Such use of technology patents as end products to generate revenue, rather than as means to develop products, is a socially controversial if not uncommon business practice that is applied to research tools in biology and medicine (Heller and Eisenberg 1998; Holman 2006). In particular, Dupont's business plan for exploiting these three patents, bolstered by the broad scope of the allowed claims, have complicated and arguably slowed commercial applications of oncomice to the development of new cancer drugs, as has been discussed in other forums (Marshall 2002; Blaug et al. 2004; Sharpless and DePinho 2006). The merit of the various claims allowed in these watershed patents has never been reconfirmed (or challenged) in the context of legal proceedings.

\section{Conclusion}

The development of the first genetically engineered mouse models of cancer-the oncomice-presents an instructive example of the unfolding of a scientific discovery in biology, where discoveries rarely come unilaterally or in a vacuum but rather evolve out of a melting pot of ideas, results, failures, unexpected outcomes, and collegial interactions. Irrespective of the effects of intellectual property considerations on the applications of this class of research tool, the series of publications in 19841987 reporting the discovery of distinctive transgenic mouse models of cancer has had a significant impact on cancer research, one that continues to this day. There is a large and still-growing field of research focused on the use of genetically engineered mouse models of cancer to study mechanisms by which tumors develop in different organs, and to elucidate the roles of specific oncogenes, tumor suppressors, and progression factors. Moreover, genetically engineered mouse models are increasingly being used as platforms for preclinical trials of targeted therapies, aimed at specific regulators and effectors of the capabilities that drive tumor development and progression to lethal diseases. Hundreds of mouse models of cancer affecting most organs of the body have been developed, and many are being refined into ever-more representative analogs of human cancers. Among the manifestations of this burgeoning field is the National Cancer Institute's Mouse Models of Human Cancer Consortium (MMHCC, http://emice.nci.nih.gov), which is spearheading multifaceted initiatives that are applying mouse models of cancer to further the mission of the NCI to understand and better treat human cancer. There has been considerable discussion and debate about the limitations of traditional transplant mouse models in predicting efficacy of anti-cancer drugs in the clinic (e.g., see Kerbel 2003; Sharpless and DePinho 2006). Time will tell whether genetically engineered mouse cancer models can better predict the benefits and substantively contribute to the clinical development of effective mechanismbased anti-cancer therapies.

In closing, we have sought in this historical reflection to illustrate the dynamics of discovery in biology, in a case study of an experimental approach involving genetic engineering of mice with oncogenes. We are confident, given the remarkable progress over the 20-plus years since their inception, that future efforts in academia and industry will continue to realize the promise implicit in these early discoveries. Moreover, this history also serves to exemplify a general principle about the enterprise of research, whereby focused technological breakthroughs can enable important and often unforeseeable advances in our knowledge of biology.

\section{Acknowledgments}

We thank Ralph Brinster for historical details and insights, Hannes Tkadletz (IMP, Vienna) for expert assistance in preparing the figures, and Scott Lowe, Gary Ruvkun, Terri Grodzicker, Jan Witkowski, and Harold Varmus for valuable comments on the manuscript.

\section{References}

Adams, J.M., Harris, A.W., Pinkert, C.A., Corcoran, L.M., Alexander, W.S., Cory, S., Palmiter, R.D., and Brinster, R.L. 1985. The c-myc oncogene driven by immunoglobulin enhancers induces lymphoid malignancy in transgenic mice. Nature 318: $533-538$.

Adams, T., Alpert, S., and Hanahan, D. 1987. Non-tolerance and autoantibodies to a transgenic self antigen expressed in pancreatic $\beta$-cells. Nature 325: 223-228.

Bautch, V.L., Toda, S., Hassell, J.A., and Hanahan, D. 1987. Endothelial cell tumors develop in transgenic mice carrying polyoma virus middle T oncogene. Cell 20: 529-537.

Bearss, D.J., Subler, M.A., Hundley, J.E., Troyer, D.A., Salinas, R.A., and Windle, J.J. 2000. Genetic determinants of response to chemotherapy in transgenic mouse mammary and salivary tumors. Oncogene 19: 1114-1122.

Bearss, D.J., Lee, R.J., Troyer, D.A., Pestel, L.R.G., and Windle, J.J. 2002. Differential effects of p21(WAF1/CIP1) deficiency on MMTV-ras and MMTV-myc mammary tumor properties. Cancer Res. 62: 2077-2084.

Bergers, G., Brekken, R., McMahon, J., Vu, T., Itoh, T., Tamaki, K., Tanzawa, K., Thorpe, P., Itohara, S., Werb, Z., et al. 2000. Matrix metalloproteinase-9 triggers the angiogenic switch during carcinogenesis. Nat. Cell Biol. 2: 737-744.

Bergers, G., Song, S., Meyer-Morse, N., Bergsland, E., and Hanahan, D. 2003. Benefits of targeting both pericytes and endothelial cells in tumor vasculature with kinase inhibitors. $J$. Clin. Invest. 111: 1287-1295.

Blaug, S., Chien, C., and Shuster, M.J. 2004. Managing innovation: University-industry partnerships and the licensing of the Harvard oncomouse. Nat. Biotechnol. 22: 761-763.

Bossy-Wetzel, E., Bravo, R., and Hanahan, D. 1992. Transcrip- 
tion factors JunB and c-Jun are selectively up-regulated and functionally implicated in fibrosarcoma development. Genes \& Dev. 6: 2340-2351.

Brinster, R.L., Chen, H.Y., Trumbauer, M., Senear, A.W., Warren, R., and Palmiter, R.D. 1981. Somatic expression of herpes thymidine kinase in mice following injection of a fusion gene into eggs. Cell 27: 223-231.

Brinster, R.L., Chen, H.Y., Messing, A., van Dyke, T., Levine, A.J., and Palmiter, R.D. 1984. Transgenic mice harboring SV40 T-antigen genes develop characteristic brain tumors. Cell 37: 367-379.

Casanovas, O., Hicklin, D.J., Bergers, G., and Hanahan, D. 2005. Drug resistance by evasion of of antiangiogenic targeting of VEGF signaling in late-stage pancreatic islet tumors. Cancer Cell 8: 299-309.

Chen, J., Tobin, G.J., Pipas, J.M., and Van Dyke, T. 1992. Tantigen mutant activities in vivo: Roles of p53 and pRB binding in tumorigenesis of the choroid plexus. Oncogene 7: 1167-1175.

Christofori, G., Naik, P., and Hanahan, D. 1994. A second signal supplied by insulin-like growth factor II in oncogene-induced tumorigenesis. Nature 369: 414-418.

Costantini, F. and Lacy, E. 1981. Introduction of a rabbit $\beta$-globin gene into the mouse germ line. Nature 294: 92-94.

Coussens, L.M., Tinkle, C.L., Hanahan, D., and Werb, Z. 2000. MMP-9 supplied by bone marrow-derived cells contributes to skin carcinogenesis. Cell 103: 481-490.

David, J.P., Mehic, D., Bakiri, L., Schilling, A.F., Mandic, V., Priemel, M., Idarraga, M.H., Reschke, M.O., Hoffmann, O., Amling, M., et al. 2005. Essential role of RSK2 in c-Fosdependent osteosarcoma development. J. Clin. Invest. 115: 664-672.

de Visser, K.E., Korets, L.V., and Coussens, L.M. 2005. De novo carcinogenesis promoted by chronic inflammation is B lymphocyte dependent. Cancer Cell 7: 411-423.

Egle, A., Harris, A.W., Bouillet, P., and Cory, S. 2004. Bim is a suppressor of Myc-induced mouse B cell leukemia. Proc. Nat1. Acad. Sci. 101: 6164-6169.

Eischen, C.M., Weber, J.D., Roussel, M.F., Sherr, C.J., and Cleveland, J.L. 1999. Disruption of the ARF-Mdm2-p53 tumor suppressor pathway in Myc-induced lymphomagenesis. Genes \& Dev. 13: 2658-2669.

Evers, B. and Jonkers, J. 2006. Mouse models of BRCA1 and BRCA2 deficiency: Past lessons, current understanding and future prospects. Oncogene 25: 5885-5897.

Folkman, J., Watson, K., Ingber, D., and Hanahan, D. 1989. Induction of angiogenesis during the transition from hyperplasia to neoplasia. Nature 339: 58-61.

Giraudo, E., Inoue, M., and Hanahan, D. 2004. An aminobisphosphonate targets MMP9-expressing macrophages and angiogenesis to impair cervical carcinogenesis. J. Clin. Invest. 114: 623-633.

Gordon, J.W., Scangos, G.A., Plotkin, D.J., Barbosa, J.A., and Ruddle, F.H. 1980. Genetic transformation of mouse embryos by microinjection of purified DNA. Proc. Natl. Acad. Sci. 77: 7380-7384.

Guy, C.T., Cardiff, R.D., and Muller, W.J. 1992. Induction of mammary tumors by expression of polyomavirus middle $\mathrm{T}$ oncogene: A transgenic mouse model for metastatic disease. Mol. Cell. Biol. 12: 954-961.

Hanahan, D. 1985. Heritable formation of pancreatic $\beta$-cell tumours in transgenic mice expressing recombinant insulin/ simian virus 40 oncogenes. Nature 315: 115-122.

Hanahan, D. and Folkman, J. 1996. Parameters and emerging mechanisms of the angiogenic switch during tumorigenesis. Cell 86: 353-354.
Haupt, Y., Alexander, W.S., Barri, G., Klinken, S.P., and Adams, J.M. 1991. Novel zinc finger gene implicated as myc collaborator by retrovirally accelerated lymphomagenesis in Eumyc transgenic mice. Cell 65: 753-763.

Heller, M.A. and Eisenberg, R.S. 1998. Can patents deter innovation? The anticommons in biomedical research. Science 280: 698-701.

Hemann, M.T., Fridman, J.S., Zilfou, J.T., Hernando, E., Paddison, P.J., Cordon-Cardo, C., Hannon, G.J., and Lowe, S.W. 2003. An epi-allelic series of p53 hypomorphs created by stable RNAi produces distinct tumor phenotypes in vivo. Nat. Genet. 33: 396-400.

Holman, C. 2006. Clearing a path through the patent thicket. Cell 125: 629-633.

Huang, A.L., Ostrowski, M.C., Berard, D., and Hager, G.L. 1981. Glucocorticoid regulation of the Ha-MuSV p21 gene conferred by sequences from mouse mammary tumor virus. Cell 27: 245-255.

Jacks, T. 1996. Tumor suppressor gene mutations in mice. Annu. Rev. Genet. 30: 603-636.

Jacobs, J.J., Scheijen, B., Voncken, J.W., Kieboom, K., Berns, A., and van Lohuizen, M. 1999. Bmi-1 collaborates with c-Myc in tumorigenesis by inhibiting c-Myc-induced apoptosis via INK4a/ARF. Genes \& Dev. 13: 2678-2690.

Jaenisch, R. and Mintz, B. 1974. Simian virus 40 DNA sequences in DNA of healthy adult mice derived from preimplantation blastocysts injected with viral DNA. Proc. Nat1. Acad. Sci. 71: 1250-1254.

Jochum, W., Passegue, E., and Wagner, E.F. 2001. AP-1 in mouse development and tumorigenesis. Oncogene 20: 2401-2412.

Jolicoeur, C., Hanahan, D., and Smith, K. 1994. T cell tolerance towards a transgenic $\beta$ cell antigen and transcription of endogenous pancreatic genes in the thymus. Proc. Natl. Acad. Sci. 91: 6707-6711.

Joyce, J.A., Baruch, A., Kareem Chehade, K., Nicole MeyerMorse, N., Fong-Ying Tsai, F.Y., Hager, J., Bogyo, M., and Hanahan, D. 2004. Cathepsin cysteine proteases are effectors of invasive growth and angiogenesis during multistage tumorigenesis. Cancer Cell 5: 443-453.

Joyce, J.A., Freeman, C., Meyer-Morse, N., Parish, C.R., and Hanahan, D. 2005. A functional mimetic implicates heparanase and its target heparan sulfate in tumor angiogenesis and invasion in a mouse model of multistage cancer. Oncogene 24: 4037-4051.

Kelly, P.N., Puthalakath, H., Adams, J.M., and Strasser, A. 2007. Endogenous bcl-2 is not required for the development of Eumyc-induced B cell lymphoma. Blood 109: 4907-4913.

Kerbel, R.S. 2003. Human tumor xenografts as predictive preclinical models for anticancer drug activity in humans: Better than commonly perceived-but they can be improved. Cancer Biol. Ther. 24: 134-139.

Lacey, M., Alpert, S., and Hanahan, D. 1986. Bovine papillomavirus genome elicits skin tumours in transgenic mice. $\mathrm{Na}$ ture 322: 609-612.

Land, H., Parada, L.F., and Weinberg, R.A. 1983. Tumorigenic conversion of primary embryo fibroblasts requires at least two cooperating oncogenes. Nature 304: 596-602.

Langdon, W.Y., Harris, A.W., Cory, S., and Adams, J.M. 1986. The c-myc oncogene perturbs B lymphocyte development in E-mu-myc transgenic mice. Cell 47: 11-18.

Leder, P. and Stewart, T. 1988. Transgenic non-human mammals. US Patent 4736866.

Leder, P. and Stewart, T. 1992. Method for providing a cell culture from a transgenic non-human mammals. US Patent 5087571.

Leder, P. and Stewart, T. 1999. Testing method using transgenic 
mice expressing an oncogene. U.S. Patent 5925803.

Leder, A., Pattengale, P.K., Kuo, A., Stewart, T.A., and Leder, P. 1986. Consequences of widespread deregulation of the c-myc gene in transgenic mice: Multiple neoplasms and normal development. Cell 45: 485-495.

Marshall, E. 2002. Dupont ups the ante on use of Harvard's oncomouse. Science 296: 1212-1213.

McCarthy, S.A., Symonds, H.S., and Van Dyke, T. 1994. Regulation of apoptosis in transgenic mice by simian virus $40 \mathrm{~T}$ antigen-mediated inactivation of p53. Proc. Natl. Acad. Sci. 91: 3979-3983.

Nozawa, H., Chiu, C., and Hanahan, D. 2006. Infiltrating neutrophils mediate the initial angiogenic switch in a mouse model of multistage carcinogenesis. Proc. Natl. Acad. Sci. 103: $12493-12498$.

Ornitz, D.M., Palmiter, R.D., Messing, A., Hammer, R.E., Pinkert, C.A., and Brinster, R.L. 1985. Elastase I promoter directs expression of human growth hormone and SV40 Tantigen genes to pancreatic acinar cells in transgenic mice. Cold Spring Harb. Symp. Quant. Biol. 50: 399-409.

Ornitz, D.M., Hammer, R.E., Messing, A., Palmiter, R.D., and Brinster, R.L. 1987. Pancreatic neoplasia induced by SV40 $\mathrm{T}$-antigen expression in acinar cells of transgenic mice. Science 238: 188-193.

Palmiter, R.D. and Brinster, R.L. 1986. Germ-line transformation of mice. Annu. Rev. Genet. 20: 465-499.

Palmiter, R.D., Brinster, R.L., Hammer, R.E., Trumbauer, M.E., Rosenfeld, M.G., Birnbberg, N.C., and Evans, R.M. 1982a. Dramatic growth of mice that develop from eggs microinjected with metallothionein-growth hormone fusion genes. Nature 300: 611-615.

Palmiter, R.D., Chen, H.Y., and Brinster, R.L. 1982b. Differential regulation of metallothionein-thymidine kinase fusion genes in transgenic mice and their offspring. Cell 29: 701710.

Palmiter, R.D., Norstedt, G., Gelinas, R.E., Hammer, R.E., and Brinster, R.L. 1983. Metallothionein-human growth hormone genes stimulate growth of mice. Science 222: 809-814.

Palmiter, R.D., Chen, H.Y., Messing, A., and Brinster, R.L. 1985. SV40 enhancer and large-T antigen are instrumental in development of choroids plexus tumors in transgenic mice. Nature 316: 457-460.

Perl, A.K., Wilgenbus, P., Dahl, U., Semb, H., and Christofori, G. 1998. A causal role for E-cadherin in the transition from adenoma to carcinoma. Nature 392: 190-193.

Quaife, C.J., Pinkert, C.A., Ornitz, D.M., Palmiter, R.D., and Brinster, R.L. 1987. Pancreatic neoplasia induced by ras expression in acinar cells of transgenic mice. Cell 48: 10231034.

Ray, D., Terao, Y., Fuhrken, P.G., Ma, Z.Q., DeMayo, F.J., Christov, K., Heerema, N.A., Franks, R., Tsai, S.Y., Papoutsakis, E.T., et al. 2007. Deregulated CDC25A expression promotes mammary tumorigenesis with genomic instability. Cancer Res. 67: 984-991.

Rüther, U., Garber, C., Komitowski, D., Muller, R., and Wagner, E.F. 1987. Deregulated c-fos expression interferes with normal bone development in transgenic mice. Nature 325: 412 416.

Rüther, U., Komitowski, D., Schubert, F.R., and Wagner, E.F. 1989. c-fos expression induces bone tumors in transgenic mice. Oncogene 4: 861-865.

Schmitt, C.A., McCurrach, M.E., de Stanchina, E., Wallace-Brodeur, R.R., and Lowe, S.W. 1999. INK4a/ARF mutations accelerate lymphomagenesis and promote chemoresistance by disabling p53. Genes \& Dev. 13: 2670-2677.

Schmitt, C.A., Rosenthal, C.T., and Lowe, S.W. 2000. Genetic analysis of chemoresistance in primary murine lymphomas. Nat. Med. 6: 1029-1035.

Schmitt, C.A., Fridman, J.S., Yang, M., Lee, S., Baranov, E., Hoffman, R.M., and Lowe, S.W. 2002. A senescence program controlled by p53 and p16INK4a contributes to the outcome of cancer therapy. Cell 109: 335-346.

Sharpless, N.E. and DePinho, R.A. 2006. The mighty mouse: The role of mouse models in cancer drug development. Nat. Rev. Drug Disc. 5: 741-754.

Sinn, E., Muller, W., Pattengale, P., Tepler, I., Wallace, R., and Leder, P. 1987. Coexpression of MMTV/v-Ha-ras and MMTV/c-myc genes in transgenic mice: Synergistic action of oncogenes in vivo. Cell 49: 465-475.

Smith, K.M., Olson, D., Hirose, R., and Hanahan, D. 1997. Pancreatic gene expression in rare cells of thymic medulla: Evidence for functional contribution to $\mathrm{T}$ cell tolerance. Int. Immunol. 9: 1355-1365.

Stewart, T.A., Wagner, E.F., and Mintz, B. 1982. Human $\beta$-globin gene sequences injected into mouse eggs, retained in adults, and transmitted to progeny. Science 217: 1046-1048.

Stewart, T.A., Pattengale, P.K., and Leder, P. 1984. Spontaneous mammary adenocarcinomas in transgenic mice that carry and express MTV/myc fusion genes. Cell 38: 627-637.

Strasser, A., Harris, A.W., Bath, M.L., and Cory, S. 1990. Novel primitive lymphoid tumours induced in transgenic mice by cooperation between myc and bcl-2. Nature 348: 331-333.

Symonds, H., Krall, L., Remington, L., Saenz-Robles, M., Lowe, S., Jacks, T., and Van Dyke, T. 1994. p53-dependent apoptosis suppresses tumor growth and progression in vivo. Cell 78: 703-711.

Ursini-Siegel, J., Schade, B., Cardiff, R.D., and Muller, W.J. 2007. Insights from transgenic mouse models of ERBB2-induced breast cancer. Nat. Rev. Cancer 7: 389-397.

van Lohuizen, M., Verbeek, S., Scheijen, B., Wientjens, E., van der Gulden, H., and Berns, A. 1991. Identification of cooperating oncogenes in $\mathrm{E}$ mu-myc transgenic mice by provirus tagging. Cell 65: 737-752.

Vaux, D.L., Cory, S., and Adams, J.M. 1988. Bcl-2 gene promotes haemopoietic cell survival and cooperates with c-myc to immortalize pre-B cells. Nature 335: 440-442.

Wagner, E.F. 1990. On transferring genes into stem cells and mice. EMBO I. 9: 3024-3032.

Wagner, E.F., Stewart, T.A., and Mintz, B. 1981. The human $\beta$-globin gene and a functional viral thymidine kinase gene in developing mice. Proc. Natl. Acad. Sci. 78: 5016-5020.

Wang, Z.Q., Liang, J., Schellander, K., Wagner, E.F., and Grigoriadis, A.E. 1995. c-fos-induced osteosarcoma formation in transgenic mice: Cooperativity with $c$-jun and the role of endogenous c-fos. Cancer Res. 55: 6244-6251.

Wendel, H.G., de Stanchina, E., Fridman, J.S., Malina, A., Ray, S., Kogan, S., Cordon-Cardo, C., Pelletier, J., and Lowe, S.W. 2004. Survival signalling by Akt and eIF4E in oncogenesis and cancer therapy. Nature 428: 332-337.

Williams, R.L., Courtneidge, S.A., and Wagner, E.F. 1988. Embryonic lethalities and endothelial tumors in chimeric mice expressing polyoma virus middle T oncogene. Cell 52: 121131.

Xian, X., Hakansson, J., Stahlberg, A., Lindblom, P., Betsholtz, C., Gerhardt, H., and Semb, H. 2006. Pericytes limit tumor cell metastasis. J. Clin. Invest. 116: 642-651. 


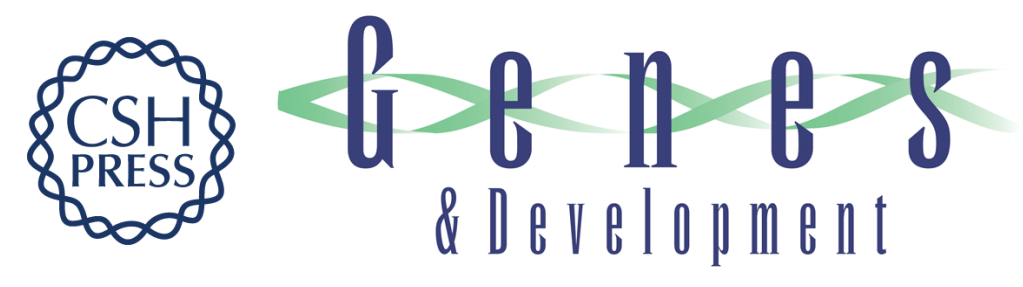

\section{The origins of oncomice: a history of the first transgenic mice genetically engineered to develop cancer}

Douglas Hanahan, Erwin F. Wagner and Richard D. Palmiter

Genes Dev. 2007, 21:

Access the most recent version at doi:10.1101/gad.1583307

Supplemental http://genesdev.cshlp.org/content/suppl/2007/08/31/21.18.2258.DC1
Material

References This article cites 79 articles, 22 of which can be accessed free at:

http://genesdev.cshlp.org/content/21/18/2258.full.html\#ref-list-1

License Freely available online through the Genes \& Development Open Access option.

Email Alerting Receive free email alerts when new articles cite this article - sign up in the box at the top

Service right corner of the article or click here.

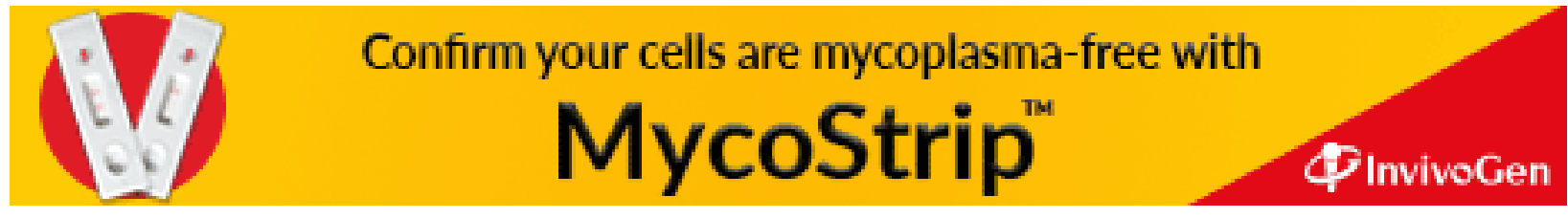

